\title{
Life as a child in Poland in World War II
}

\author{
https://doi.org/10.51167/ice00005
}

\section{Asher Mandelbaum (1934 - 2020)}

I was born in Krakow, Poland, in late December 1934. World War II broke out when I was nearly five years old and it changed the entire course of our lives. When the war erupted, my father happened to be in Lvov on business. The city was occupied by the Russians and he was exiled to labor camps in Siberia and Uzbekistan. When Krakow was occupied by the Germans (in September 1939) my mother took me and my younger sister Dina to her parents in Koszyce, a small town about $50 \mathrm{~km}$ from Krakow.

Edicts against the Jewish community were published a short time after we arrived in Koszyce. The synagogues were closed and it was forbidden to pray together even in private homes. The Jewish school was closed and the education of Jewish children was prohibited in any form or setting. A short time after the occupation, Jews became obliged to wear identification tags (a blue Star of David) on their sleeves. Towards the winter of 1941, the occupying forces confiscated all furs belonging to Jews and these were transferred to the German army stationed on the Eastern front. Various limitations were set on the employment of Jews, and the Jewish Committee was often required to pay fines. In the second half of 1942, all Jews residing in the cities and towns were concentrated in ghettos and concentration camps and their final extermination began. The Jewish Committee in Koszyce succeeded in postponing the deportation a couple of times until November 1942 by bribing the German commander.

In the period preceding the deportation, my grandfather, Yaakov Kaminsky, contacted a young Pole, Janek Młynarczyk, from the small village of Górka near Koszyce, who was ready to help save our family. To this day, I cannot understand why Janek agreed to assume this dangerous and difficult task. The German authorities declared that helping Jews would result in a death sentence, both for those guilty of providing assistance and for their entire families. I have never received a satisfying answer to this conundrum despite my correspondence with Janek and his wife and a long conversation with them in Poland in 1998. His great appreciation for my grandfather was apparent and he repeatedly declared that he did what he did "because Pan Kaminsky said so".

On a night in November 1942, the Jews of Koszyce were gathered in the town square and taken in trucks to a concentration camp, where nearly all of them were killed. The night before, Janek had transferred our family to his uncle's house in the small village of Szczelce. Fifteen people crowded

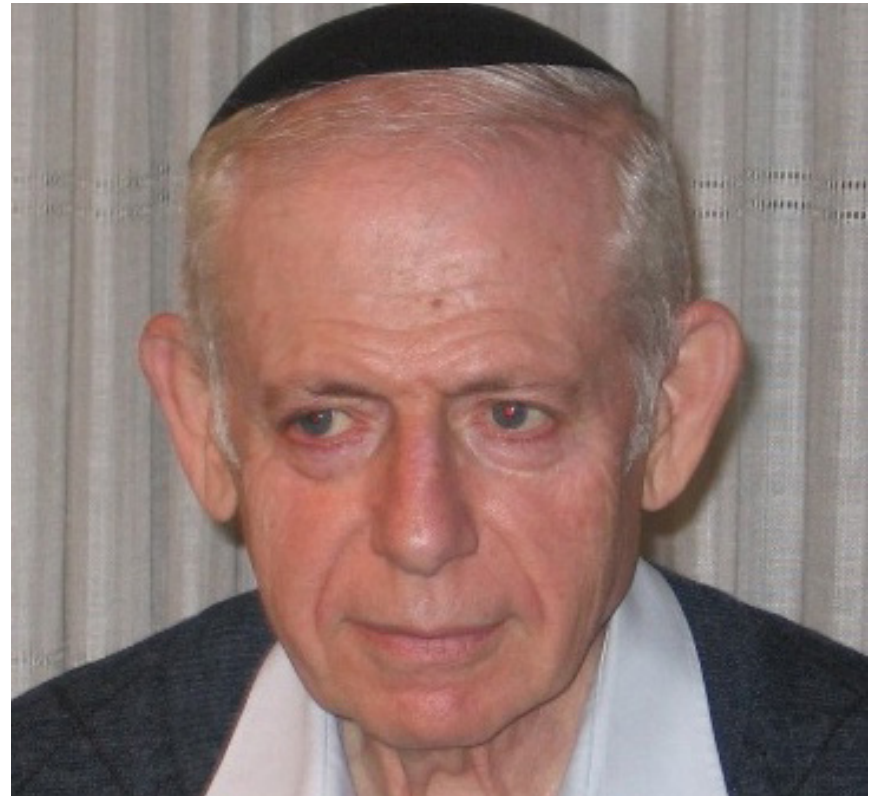

together into a dark cellar: my mother, my four-year-old sister, myself (eight years old), my grandmother and other relatives. My grandfather, who was a member of the Jewish Committee, did not join us. He was taken to the concentration camp with the other Jews of Koszyce, where he died.

After about two weeks in Szczelce, Janek transferred us to the ghetto the Nazis had formed in the town of Bochnia, about $50 \mathrm{~km}$ from Krakow, where we spent the winter of 1942/3. I remember that the ghetto was terribly crowded, both in the living quarters and in the streets. The winter was extremely cold and means of heating were very scarce. There was also a constant shortage of food. The most difficult problem was our uncertainty regarding the future. Towards the spring of 1942, rumors abounded about the approaching liquidation of the ghetto.

Despite the dangers, Janek succeeded in entering the ghetto and consulting with my grandmother and mother concerning our next moves. In light of the constant rumors, it seemed that it would be dangerous to remain and we must find another solution. They felt that my grandmother, my sister and my grandmother's sister looked sufficiently Polish to enable them to acquire false identities and present themselves as Poles in distant locations, where there was no reasonable chance of meeting acquaintances. Equipped with false documents they moved to Warsaw, where they remained until the partisan revolt in 1944. However, my mother and I looked Jewish and could not avail ourselves of this solution so we needed to find a hiding place. 
The first stage was to leave the ghetto. Janek succeeded in bribing a German officer (not an easy venture, but it is beyond the scope of this short summary), and on an evening in May 1943 I left the Bochnia ghetto with my mother in a German army car and we arrived on the outskirts of the village of Szczurowa, between Bochnia and Koszyce. Janek was waiting for us nearby and he led us in the dark to a small wooden hut belonging to his relatives. The hut consisted of only one room with a little attic and it was occupied by three brothers. They used the only downstairs room and we received the attic, which could only be reached by ladder. Janek was aware of the anti-Semitic views of his fellow Poles (and of his own relatives) and he introduced us as political refugees fleeing the occupying forces and warned us to avoid any mark of Jewishness.

One evening, after we had been in this hiding place for about two weeks, my mother heard the brothers discussing us at supper and sensed that they suspected we were Jews. She decided that it would be dangerous to remain there, and when our hosts fell asleep we left the hut. The only person we could trust was Janek and we set out to find him. After walking all night on unknown and unmarked roads, encountering German patrols which luckily did not identify us, we reached Gorka early in the morning. We were forced to ask local villagers working in the fields for directions to Janek's home. Our ordeals throughout this day are engraved in my memory as one of the most terrifying days of my life, although it will not be possible to relate everything that happened to us here.

At this stage, Janek began seeking a permanent hiding place for us. Over the next three-four weeks, he would find us temporary hiding places in friends' or relatives' barns or cellars for two-three days, where we hid in haystacks or heaps of litter; however I do not remember this period in detail. I remember the fear of our "hosts" (which was justified, considering the death penalty for those caught harboring fugitives and for their families), who brought us food upon our arrival (usually a three-day supply of bread and water) and hurried to leave home for the duration of our stay. Sometimes we found that mice had eaten from our bread. I also remember the terrible fear of moving from one hiding place to another, in the dark, at the age of $8^{1 / 2}$.

In July 1943 Janek found us a hiding place in the remote village of Młynarczyk, approximately three km from Koszyce, at the home of a church organ player, Mr. Elias, who was acquainted with my grandfather. From the beginning of the war, Mr. Elias' daughter, son-in-law and their three daughters, the Skowron family, had been staying with him, having fled Warsaw when the war broke out. Mr. Skowron had previously been employed as a civil servant and he had been a member of the fascist Polish National Democratic party (EnDe). During the war he was active in the right-wing partisan Resistance "Armia Krajowa" known for its anti-Semitism, and he stored arms and ammunition for the partisans in a small shed in his father-in-law's house. Discovery of this shed and its contents by the Germans would undoubtedly have brought the death penalty upon the entire family. Therefore, Janek assumed that it would be easier to convince them to hide us in the shed. At first, Mr. Elias strongly objected, but upon hearing that my mother was the daughter of Mr. Kaminsky he gradually relented. The fee that was promised also contributed to his decision.

I will attempt to describe the designated hiding place. It was about two meters long and a maximum of $1 \frac{1 / 2}{2}$ meters wide. A wide wooden plank slightly less than two meters long was placed on two barrels along the length of the shed, covered by a few sacks of straw. This plank, which occupied most of the shed, served as our bed, table, bench, and everything else. Opposite this bed, along the shed's wall, were shelves heaped with arms and ammunition. Above the "bed" Mr. Skowron installed a larger shelf for us, which served us as a table and work surface. He blocked the entrance to the shed with planks and hid it from strange eyes. He also uprooted a few planks from the floor of the dining room, which bordered with the bunker, and he dug a small tunnel under the floor through which it was possible to crawl. This tunnel served for the daily passage of food and water and the removal of our waste. The bunker's "furniture" ("table", "bed" and shelves) and the tunnel opening left hardly any free space to stand or walk.

Our bunker allowed no light. Rachwałowice, similar to most Polish villages at the time, was not connected to the electricity network (there was also no running water or telephones), and there was a shortage of fuel due to the war. Skowron brought us a carbide lamp, which gave off white light which enabled some activity in these harsh conditions. The operation of this lamp was probably my first chemical experiment:

$$
\underset{\text { calcium carbide }}{\mathrm{CaC}_{2}}+\underset{\text { acetylene }}{\mathrm{H}_{2} \mathrm{O}} \rightarrow \underset{\text { HCCH }}{\mathrm{HaO}}
$$

A tap is opened, causing contact between carbide and water and the formation of acetylene, and when the latter burns it produces an open light. Under normal conditions, I would not advise using such a lamp for lighting purposes, certainly not in a small closed room. At the time, the carbide lamp was an essential part of our mental survival.

We hid in this bunker for a year and a half, from July 1943 until the second half of January 1945. We had two books, the first was the famous classical poem "Pan Tadeusz" by Adam Mickiewicz, and the second was a geographical encyclopedia. I read both books many times, and by the time of our liberation, 
I almost knew "Pan Tadeusz" by heart. Another occupation was knitting sweaters and socks for the Skowron family and for ourselves. I acquired a not insignificant proficiency in this craft. Under Janek's direction, Mr. Skowron bought the wool in small quantities in a distant town in order to avoid attracting the neighbors' attention. He used this method for other shopping as well.

Throughout our prolonged stay in the bunker, my mother devoted much time to teaching me as many subjects and topics as she could in the absence of textbooks. She taught me the Hebrew alphabet, and also prayers she knew by rote. During the months of September-October and April she asked Mr. Skowron about changes in the shape of the moon, and accordingly estimated when Yom Kippur and Pesach occurred; she fasted on the former and avoided eating bread during the latter.

Due to Mr. Skowron's membership in the Resistance we received news bulletins with information about the various fronts. I remember our joy on a morning in June 1944, when we heard about the allied forces' landing in Normandy (6.6.1944). From here on, the news we heard signaled that the end of the war was near and with it the end of our troubles.

One night we heard the frightening noise of an airplane. Skowron told us that that night a British plane had landed near the cemetery of Rachwałowice, unloaded a shipment of arms and a high-powered transmitter, and left carrying one of the Resistance leaders. Skowron brought some of the equipment to our bunker, luckily not assisted by his comrades. This sign from the free world gave us a wonderful feeling but we were also frightened of possible German searches as they had probably noticed the planes as well.

The Red Army offensive began towards the end of 1944 . After waiting for about a year on the eastern bank of the Vistula (Wisla), they crossed the river at a number of points and drew near us. The German army started to retreat, and many trucks passed Rachwałowice on their way west, very close to our hiding place. Skowron reported with concern that the Germans wished to establish their headquarters in Rachwałowice, and that the village chief had offered them our house. For three days the Skowrons deliberated how to solve the problem, which could put their entire family (and us too) in risk of facing a firing squad, although we were so close to liberation. Luckily, the German commander thought that the house of the village chief would be a more suitable headquarters, thereby solving one of the most serious threats to our survival. But the danger was not yet over. Two German officers were stationed at our house, and the room they chose was the dining room that bordered with our bunker, into which our tunnel opened. It was terrifying to hear the hobnailed boots of our neighbors on the other side of the wall. The Skowrons were frightened too, lest the officers would discover the tunnel's opening, and reduced their contact with us to bringing water and food and removing our waste.

In early January 1945, close to my tenth birthday, the German army began their panicked flight westwards. In our area, they suffered a shortage of fuel, and in their flight they used horses and carts confiscated from villages on the way. Although the bunker was impermeable, we heard them prodding the horses past our house for three days and three nights.

Krakow was liberated by the Red Army on January 19th 1945, and the Russians arrived in Rachwałowice a few days later. Skowron made a small loophole for us in the blocked opening of the bunker so that we could see the Russian tanks passing through the village. Only the next day did Skowron allow us to leave the bunker for the dining room, and even then only for limited periods of time. Our elation upon our liberation is indescribable and I'm not certain that I can faithfully reconstruct my feelings on this special occasion. Our renewed encounter with daylight after sitting for a year and a half in a sealed bunker was a very special experience. I remember how difficult it was for me to leave the window, the view of the white winter country and the blue sky.

Our joy at the war's ending was mixed with serious questions with regard to our first steps after leaving the bunker, having been completely severed from normal life for such a long time. Janek advised us to wait a couple of days at the Skowrons, to see what would happen, and then to move to Koszyce, at least temporarily. He spoke to the family that lived in my grandfather's spacious house (the Glowacz family), and received their consent for us to stay there for some time. In the meantime, the Skowrons did their utmost to keep our existence hidden from their anti-Semitic neighbors, who might have killed them and us all.

A couple of days after the liberation, early on a cold and snowy Sunday, when all the villagers were still asleep, we left on foot for Koszyce, a distance of about three $\mathrm{km}$. After a while I could not continue walking. A year and a half in a small bunker without movement had caused my muscles to atrophy, making it very difficult to walk. Skowron carried me for most of the way (I did not weigh much), and thus we arrived that morning in Koszyce. Janek directed my grandmother and my sister (whom he had also cared for throughout that period) to Koszyce as well and took us all by horse and carriage to Krakow, a distance of about $50 \mathrm{~km}$. A few holocaust survivors who had succeeded in remaining alive gathered together - some had survived in hiding, some with the Resistance or in concentration camps. Immediately after the war, the refugees established a Jewish committee which took care of 
all their needs, for example living quarters, jobs, reactivating synagogues, founding and operating Jewish schools, etc. At the Jewish school "Tarbut" we studied intensively for three years in order to complete all the material we had missed during the war. In the summer of 1946, my father returned from Russia and our family was reunited after being separated for almost seven years.

Janek's contribution to our rescue was crucial, although, as I have mentioned, to this day we do not know the motivation for his actions. Throughout the entire period, he was exposed to daily life-threatening danger in his attempts to find us shortand long-term hiding places, transferring us from one hiding place to the other, by foot or by carriage, and locating money that my grandfather had deposited with neighbors with whom he was befriended, to pay for our monthly lodgings and my grandmother and sister's expenses in Warsaw. Yanek and the Skowrons were acknowledged as righteous gentiles by "Yad Vashem".

In early 1948, a short time after my bar-mitzvah, our family received permission to leave Poland. In March of that year we left Poland for France. After a short stay in Paris we traveled to the sea port of Marseilles, where we joined a Jewish Agency immigrants' camp. We arrived in Israel on the French boat "Providence" as part of the "Aliya D", equipped with a real Polish passport, a real visa to Bolivia (purchased from the Consul in Paris), a false transit visa through Palestine and the address of an imaginary relative in Tel-Aviv, whom we were allegedly going to visit on our way to Bolivia. We were on the deck of the boat on Friday, Iyar 5th, May 14th, 1948, when we heard over the loudspeakers that the State of Israel had been established. Our joy was subdued; we all knew that a new war was about to begin, three years after the terrible last war had ended. The next day we reached the Port of Haifa, from where we were taken to the immigration camp in the sands of Kiryat Shmuel (present day Kiryat Yam), and about two weeks later we moved to a rental apartment in Haifa.

At this point a new chapter began in my life. In the autumn of 1948, I began my studies in Israel at the "Netzah Yisrael" school in Haifa, where I enrolled in the 8th grade. During the years 1949-1953, I studied at the religious "Yavneh" high school in Haifa and after my military service during 19531955, I began studying at the Technion Faculty of Chemical Engineering.

During the second year of my studies I participated in two courses in organic chemistry given by the late Prof. David Ginzburg. The courses were jointly addressed to students of the Faculty of Chemical Engineering (about 70 students) and students of the Faculty of Sciences - Chemistry (about 10 students). Professor Ginzburg succeeded in transforming the study of organic chemistry into the most fascinating experience, and as a result I decided towards the end of my second year to transfer to the Faculty of Sciences - Chemistry, which later became the Faculty of Chemistry.

In November 1958 my life changed when I married Leah Faber, who was (and still is) my sister's best friend. In 1960 and 1961 our two sons, Moshe and Yitzhak, were born, and in 1967 and 1969 our two daughters, Aviva and Ilana.

In 1959, I finished my undergraduate studies and received my BSc. About a year later I received the degree of MSc for developing a new method for synthesis of triphenylenes, supervised by Dr. Michael Cais, a new faculty member. Prof. Cais served as the supervisor also for my doctorate thesis (1960-1963) on isolating and determining the structure of the components of the narcotic plant Catha Edulis. In this research, we used mass spectrometry to determine the molecular weight and structure of one of the plant's components. Since in 1963 there was no mass spectrometer with the capacity to measure high molecular weights (up to 1000 dalton) in Israel, the mass spectra were measured in the laboratory of Prof. Carl Djerassi at Stanford University in the US. Following the success of this method for determining the structure of organic materials, Prof. Ginsburg decided to establish an organic mass spectrometry laboratory at the Technion. Towards the end of 1963, an Atlas CH4 mass spectrometer was purchased, and I was offered to serve as a faculty staff member with the rank of lecturer and as head of the new laboratory.

One of the first projects we performed with the new equipment was investigating the fragmentation of various derivatives of morphine, provided by Prof. Ginzburg from his large collection. Amongst the materials examined were a number of stereoisomers differing in the configuration at position 14 of the morphine system. To our surprise, the mass spectra of the stereoisomers were entirely different, and the differences indicated stereospecific fragmentation mechanisms. The standard opinion at the time was that due to the relatively high energy in the electronic ionization process, the ions created undergo isomerization to the most stable structures, and therefore there should be no expectation of differences between the mass spectra of stereoisomers. This view was disproved by our observation, which later led to many studies performed by the Technion's mass spectrometry group.

Prof. Mandelbaum passed away on 21st June, 2020. Further details of his academic career can be found at https:// chemistry.technion.ac.il/wp-content/uploads/2019/10/ Memoirs September 2019-1 compressednew-1.pdf 